\title{
Denim Kumaşlarda Farklı Yıkama İşlemlerinin Kumaşların Fiziksel Özellikleri Üzerindeki Etkilerinin Araştırılması
}

\author{
Eylen Sema DALBAŞI ${ }^{* 1}$, Gonca ÖZÇELİK KAYSERİ ${ }^{2}$ \\ ${ }^{1}$ Ege Üniversitesi, Tekstil Mühendisliği Bölümü, Bornova, İzmir \\ ${ }^{2}$ Ege Üniversitesi, Emel Akın Meslek Yüksek Okulu, Bornova, İzmir
}

Geliş tarihi: 03.01.2018 Kabul tarihi: 14.03 .2018

\section{$\ddot{\mathbf{O} z}$}

$\mathrm{Bu}$ çalışmada, denim terbiyesinde uygulanan çeşitli yıkama ve ağartma işlemlerinin denim kumaşların gramaj, en büyük kopma kuvveti, eğilme dayanımı, yüzey sürtünme katsayısı ve renk değişimi gibi fiziksel özellikleri üzerine etkisi incelenmiştir. Bu amaçla; denim kumaşlara taş yıkama, enzim yıkama, taş ve enzim yıkama, peroksit ağartma, hipoklorit ve potasyum permanganat ağartması gibi çeşitli yıkama işlemleri uygulanmıştır. Elde edilen sonuçlar istatistiksel olarak değerlendirilmiştir. Denim kumaşlarda istenen soldurma etkisi en fazla taş yıkama, enzim yıkama ve peroksit ağartma ile elde edilmiştir. Ancak mukavemet kayıpları dikkate alındığında peroksit ağartma uygulanan kumaşlarda mukavemet kaybı yüksek olduğu için en uygun denim yıkama prosesinin taş ve enzim yıkama olduğu belirlenmiştir.

Anahtar kelimeler: Denim kumaş, Taş yıkama, Enzim yıkama, Ağartma, Fiziksel özellikler

\section{Investigation of the Different Washing Processes on the Physical Characteristics of Denim Fabrics}

\begin{abstract}
In this study, the effect of various washing and bleaching treatments on the physical properties of denim fabrics such as weight, breaking strength, bending rigidity, surface friction coefficient and color change were investigated. For this purpose; the various washing processes such as stone washing, enzymatic washing, stone and enzyme washing, peroxide bleaching, hypochlorite and potassium permanganate bleaching were applied to denim fabrics. The results obtained were evaluated statistically. The desired fading effect in denim fabrics was obtained by maximum stone washing, enzyme washing and peroxide bleaching. Considering the strength losses, however, it was determined that the most suitable washing processes were stone washing and enzyme washing because of the high loss of strength in bleached fabrics with peroxide.
\end{abstract}

Key words: Denim fabric, Stone wash, Enzymatic washing, Bleaching, Physical properties

\footnotetext{
*Sorumlu yazar (Corresponding author): Eylen Sema DALBAȘI, sema.namligoz@ege.edu.tr
} 


\section{GíRiş}

Moda akımının önemli bir kısmını oluşturan denim giysiler, ilk olarak 19. yüzyılın ortasında üretilmiştir. Amerika'da önceleri köylü ve işçilerin giydiği bir pantolon çeşidi olan denim ya da yaygın kullanım adıyla blue-jean, II. Dünya Savaşı sırasında tüm dünyaya yayılmıştır. İlk denim kumaş üretimi 1873 yılında Levi Strauss \& Co tarafından yapılmıştır. Firmanın başlattı̆̆ı denim giysi akımı, 1950'lerde ilk fermuarlı jeanlerle birlikte dünya çapında giderek yaygınlaşmaya başlamıştır. Günümüzde denimden yapılan giysiler, genç yaşlı her kesimden insanın tercih ettiği giysilerdir. Bunun sebebi; görünümün ötesinde denim kumaşların rahatlığı, dayanıklılığı, estetik ve moda akımına uygun olmasıdır [1].

Denim kumaşlar konfeksiyon alanında katma değeri yüksek ürünler olup dimi konstrüksiyonunda ve genellikle pamuktan üretilmektedirler. Denim kumaşlara uygulanan farklı yıkama işlemleri ile modaya uygun çok çeşitli efektler elde edilmektedir. Denim kumaşlarda atkı ipliği olarak boyanmamış, çözgü ipliği olarak da indigo boyarmaddeyle boyalı iplikler kullanılmaktadır ve yıkama işlemleri sırasında kumaşın rengi ve tonu değişmektedir [2-5].

Denim kumaşlara yapılan işlemler enzim yıkama, taş yıkama, rinse yıkama, moon yıkama, kumla işlem, ağartma şeklinde sıralanabilir [6-8]. Taş yıkama, denim kumaşlarda en sık kullanılan yıkama uygulamalarından biridir. Taş yıkama işleminde amaç, denim ürünlere, uzun süre giyilmiş ve birçok kez yıkanmış efekti kazandırmaktır. Taş yıkama sırasında kullanılan ponza taşları aşındırma etkisiyle kumaşın renginin açılmasını sağlamaktadırlar. Ayrıca denim kumaş solmuş görünüm kazanmaktadır. Ancak kullanılan ponza taşları makine parçalarına zarar vermekte, drenaj sistemlerinin tıkanmasına sebep olmakta ve taş parçacıklarının uzaklaştırılması zor olmaktadır. Ayrıca, taş yıkama sonrasında kumaşın dikiş, kemer ve kenar kısımları zarar görebilmektedir $[9,10]$. Enzimlerle işlem sonrasında selülozik kumaşların yüzeyindeki lifler uzaklaştırılmakta, pilling oluşumu azalmakta ve tuşe yumuşamaktadır [11]. Denim ürünlerde ise, selülaz enzimi kullanılarak yapılan biyoparlatma olarak adlandırılan bu yıkama işlemi ile indigo boyarmadde kumaştan uzaklaştırılmakta ve denim kumaşa eskitme efekti kazandırılmaktadır. Bu işlemde daha çok asidik veya nötral selülazlar tercih edilmektedir [1,9]. Denim kumaşlarda ağartma, görünümü kar beyazlığına kadar ulaşabilen rengi tanımlamaktadır. Denim kumaşlarda haşıl söküldükten sonra taş yıkama yapılıp veya taş yıkama yapılmadan ağartma işlemi uygulanarak kumaşın rengi istenilen tonda açılmaktadır. Genellikle ağartma işlemlerinde sodyum hipoklorit ağartması, potasyum persülfat ağartmas1, enzimatik ağartma, permanganat ağartması ve peroksit ağartması olmak üzere beş yöntem uygulanmaktadır [12].

$\mathrm{Bu}$ çalışmada, denim terbiyesinde uygulanan çeşitli yıkama ve ağartma işlemlerinin denim kumaşların gramaj, en büyük kopma kuvveti, eğilme dayanımı, yüzey sürtünme katsayısı ve renk değişimi gibi fiziksel özellikleri üzerine etkisi incelenmiştir. $\mathrm{Bu}$ amaçla, denim kumaşlara taş yıkama, enzim yıkama, taş ve enzim yıkama, peroksit ağartması, hipoklorit ve potasyum permanganat ağartması gibi çeşitli yıkama ve ağartma işlemleri uygulanmıştır. Elde edilen sonuçlar üzerine uygulanan yıkama, ağartma işlemlerinin ve yıkama sayısının etkisi istatistiksel olarak değerlendirilmiştir.

\section{MATERYAL VE METOT}

\subsection{Materyal}

Bu çalışmada, denim kumaşlar bir firmadan temin edilmiştir. Bu kumaşlara haşıl sökme işleminden sonra taş yıkama, taş ve enzim yıkama, enzim yıkama, peroksit, hipoklorit ve potasyum permanganat olmak üzere 6 farklı parça yıkama işlemi yapılmıştır. Çizelge 1'de kumaşın fiziksel özellikleri ve Çizelge 2'de parça yıkama işlemleri ve kumaş kodları verilmektedir.

Çizelge 1. Denim kumaşın fiziksel özellikleri

\begin{tabular}{|c|c|c|}
\hline \multicolumn{2}{|c|}{ Doku tipi } & $3 / 1$ dimi \\
\hline \multicolumn{2}{|c|}{ Gramaj $\left(g / m^{2}\right)$} & 416 \\
\hline \multirow{2}{*}{ Sıklık } & Çözgü sıklığ1 (tel/cm) & 26 \\
\hline & Atk1 sıklığ1 (tel/cm) & 16 \\
\hline
\end{tabular}


Çizelge 2. Parça yıkama işlemleri ve kumaş kodlar1

\begin{tabular}{|l|c|}
\hline İşlem adı & Kodlar \\
\hline İşlemsiz & İG \\
\hline Taş yıkama & 1 \\
\hline Taş yıkama + 10 defa yıkama & $1 \mathrm{~A}$ \\
\hline Taş yıkama + 20 defa yıkama & $1 \mathrm{~B}$ \\
\hline Enzim yıkama & 2 \\
\hline Enzim yıkama + 10 defa yıkama & $2 \mathrm{~A}$ \\
\hline Enzim yıkama + 20 defa yıkama & $2 \mathrm{~B}$ \\
\hline Taş ve enzim yıkama & 3 \\
\hline Taş ve enzim yıkama + 10 defa yıkama & $3 \mathrm{~A}$ \\
\hline Taş ve enzim yıkama + 20 defa yıkama & $3 \mathrm{~B}$ \\
\hline Peroksit ağartması & 4 \\
\hline Peroksit ağartma + 10 defa yıkama & $4 \mathrm{~A}$ \\
\hline Peroksit ağartması + 20 defa yıkama & $4 \mathrm{~B}$ \\
\hline Hipoklorit ağartması & 5 \\
\hline Hipoklorit ağartması + 10 defa yıkama & $5 \mathrm{~A}$ \\
\hline Hipoklorit ağartması + 20 defa yıkama & $5 \mathrm{~B}$ \\
\hline Potasyum permanganat ağartması & 6 \\
\hline $\begin{array}{l}\text { Potasyum permanganat ağartması + 10 } \\
\text { defa yıkama }\end{array}$ & $6 \mathrm{~A}$ \\
\hline $\begin{array}{l}\text { Potasyum permanganat ağartması }+ \\
\text { defa yıkama }\end{array}$ & $6 \mathrm{~B}$ \\
\hline
\end{tabular}

Çizelge 3'de denim kumaşlara uygulanan yıkama ve ağartma işlemlerinde kullanılan kimyasal maddelere ait bilgiler verilmektedir.

Çizelge 3. Kullanılan kimyasal maddeler

\begin{tabular}{|l|l|}
\hline $\begin{array}{l}\text { Kimyasal } \\
\text { maddenin adı }\end{array}$ & Kimyasal maddenin yapısı \\
\hline Islatıcı & $\begin{array}{l}\text { Sülfone edilmiş alkan ve yağ alkolü } \\
\text { etoksilatları karı̧ımı, anyonik }\end{array}$ \\
\hline Selülaz enzimi & Endoca zengin asidik selülaz enzimi \\
\hline Amilaz enzimi & Bakteri amilazı \\
\hline Yıkama maddesi & $\begin{array}{l}\text { Yağ alkolü etoksilatlarının karısımı, } \\
\text { noniyonik }\end{array}$ \\
\hline Dispergatör & $\begin{array}{l}\text { Yüksek moleküllü etoksilatların } \\
\text { sinerjetik karışımı }\end{array}$ \\
\hline $\begin{array}{l}\text { Potasyum } \\
\text { permanganat }\end{array}$ & $\mathrm{KMnO}_{4}$ \\
\hline Asetik asit & $\mathrm{CH}_{3} \mathrm{COOH}$ \\
\hline Sodyum bisülfit & $\mathrm{NaHSO}_{3}$ \\
\hline Sodyum karbonat & $\mathrm{Na}_{2} \mathrm{CO}_{3}$ \\
\hline Hidrojen peroksit & $\mathrm{H}_{2} \mathrm{O}_{2}\left(\% 50{ }^{\prime}\right.$ lik) \\
\hline $\begin{array}{l}\text { Sodyum } \\
\text { hipoklorit }\end{array}$ & $\mathrm{NaOCl}$ \\
\hline Ponza taşı & \\
\hline
\end{tabular}

\subsection{Metot}

Yapılan tüm parça yıkama ve ağartma işlemleri, Rapid Laborteks marka tamburlu numune parça yıkama makinesinde gerçekleştirilmiştir. Parça yıkama işlemlerinden önce tüm kumaşlarda haşıl sökme işlemi aynı makinede yapılmıştır. Kullanılan haşıl sökme reçetesi Çizelge 4'de verilmektedir.

Çizelge 4. Haşıl sökme reçetesi

\begin{tabular}{|l|}
\hline Haşıl sökme \\
\hline$\% 4$ Amilaz enzimi \\
\hline$\% 4$ Islatıcı \\
\hline Çektirme yöntemi, $70^{\circ} \mathrm{C}-20 \mathrm{dk}$ \\
Flotte oranı $1 / 20$ \\
Durulama, $25^{\circ} \mathrm{C}-15 \mathrm{dk}$ \\
\hline
\end{tabular}

Parça yıkama ve ağartma işlemlerinden sonra kumaşlar oda sıcaklığında asarak kurutulmuştur. Kurutma işleminden sonra kumaşlar 3 gruba ayrılmıştır. 1. grup kumaşlara sadece parça yıkama ve ağartma işlemleri yapılmış ve ardından testler gerçekleştirilmiştir. 2. grup kumaşlara parça yıkama ve ağartma işlemleri yapılıp ardından Wascator standart yıkama makinesinde 10 yıkama yapıldıktan sonra testler gerçekleştirilmiştir. 3 . grup kumaşlara parça yıkama ve ağartma işlemleri yapılıp ardından Wascator standart y1kama makinesinde 20 defa yıkanmıştır. Yıkamalar sonrasında testler gerçekleştirilmiştir. Şekil 1'de, iş akış şeması, parça yıkama ve ağartma işlemlerine ait aplikasyon şartları ve Çizelge 5'de ise reçeteler verilmektedir.

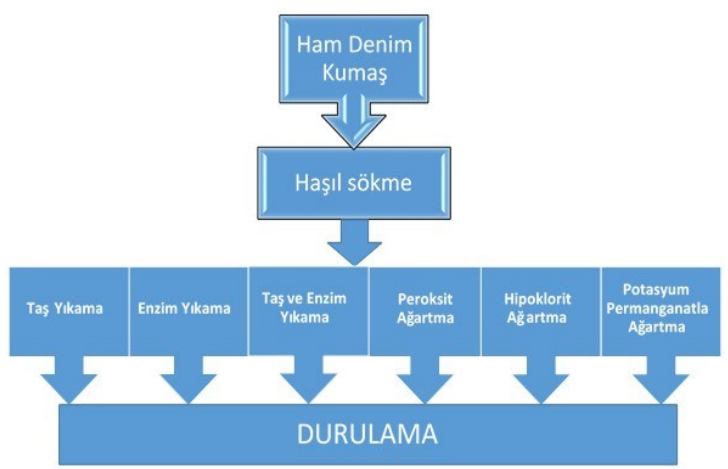

Şekil 1. İş akış şeması 
Çizelge 5. Parça yıkama ve ağartma işlemlerine ait reçeteler

\begin{tabular}{|c|c|c|}
\hline Taş yıkama & Enzimle biyoparlatma & $\begin{array}{c}\text { Taş ve Enzimle } \\
\text { yıkama }\end{array}$ \\
\hline $\begin{array}{l}\text { \%1 Ponza taş } 1 \\
\text { Çektirme, } 50^{\circ} \mathrm{C}- \\
30 \mathrm{dk} \\
\text { Flotte oranı } 1 / 30 \\
\text { Durulama, } 25^{\circ} \mathrm{C} \text { - } \\
15 \mathrm{dk}\end{array}$ & $\begin{array}{l}2 \mathrm{~g} / 1 \text { Selülaz enzimi } \\
1 \mathrm{~g} / 1 \text { Islatıc } \\
1 \mathrm{~g} / 1 \text { Dispergatör } \\
\mathrm{pH}: 4,5-5 \text { Çektirme, } \\
40{ }^{\circ} \mathrm{C}-30 \mathrm{dk} \\
\text { Flotte oran } 1 / 30 \\
\text { Durulama, } 25^{\circ} \mathrm{C}-15 \mathrm{dk} \\
\text { Nötralizasyon }(1 \mathrm{~g} / 1 \\
\left.\mathrm{NaHSO}_{3}\right) 25^{\circ} \mathrm{C}-10 \mathrm{dk}\end{array}$ & $\begin{array}{l}\text { \%1 Ponza Taş1 } \\
2 \text { g/l Selülaz enzimi } \\
1 \text { g/l Islatıc1 } \\
1 \mathrm{~g} / 1 \text { Dispergatör } \\
\mathrm{pH} \text { : } 4,5-5 \text { Çektirme, } \\
40{ }^{\circ} \mathrm{C}-30 \mathrm{dk} \\
\text { Flotte oran } 1 / 30 \\
\text { Durulama, } 25^{\circ} \mathrm{C}-15 \mathrm{dk} \\
\mathrm{Nötralizasyon}(0,5 \mathrm{~g} / 1 \\
\left.\mathrm{Na}_{2} \mathrm{CO}_{3}\right) 25^{\circ} \mathrm{C}-10 \mathrm{dk} \\
\end{array}$ \\
\hline Peroksitle & Hipokloritle ağartma & $\begin{array}{c}\text { Potasyum } \\
\text { permanganatla } \\
\text { ağartma }\end{array}$ \\
\hline $\begin{array}{l}15 \mathrm{~g} / 1 \mathrm{H}_{2} \mathrm{O}_{2} \\
4 \mathrm{~g} / 1 \mathrm{NaOH} \\
4 \mathrm{~g} / 1 \mathrm{Stabilizatör} \\
1 \mathrm{~g} / 1 \mathrm{Iyon} \text { tutucu } \\
\text { Ceektirme, } 95^{\circ} \mathrm{C}- \\
60 \mathrm{dk} \\
\text { Flotte oranı } 1 / 20 \\
\text { Y1kama }(1 \mathrm{~g} / 1 \\
\text { Tensid) } 25^{\circ} \mathrm{C}-10 \mathrm{dk} \\
\end{array}$ & $\begin{array}{l}20 \mathrm{~g} / 1 \mathrm{NaOCl} \\
1,5 \mathrm{~g} / 1 \mathrm{Na}_{2} \mathrm{CO}_{3} \\
1 \mathrm{~g} / 1 \text { Islatıc1 } \\
\text { Çektirme, } 50^{\circ} \mathrm{C}-15 \mathrm{dk} \\
\text { Flotte oran } 1 / 20 \\
\text { Nötralizasyon, } 45^{\circ} \mathrm{C}- \\
5 \mathrm{dk} \\
\text { Durulama, } 25^{\circ} \mathrm{C}-5 \mathrm{dk}\end{array}$ & $\begin{array}{l}0,3 \mathrm{~g} / 1 \mathrm{KMnO}_{4} \\
\text { Cektirme, } 55^{\circ} \mathrm{C}-20 \mathrm{dk} \\
\text { Flotte oranı } 1 / 20 \\
\text { Nötralizasyon }(3 \mathrm{~g} / 1 \\
\left.\text { NaHSO }_{3}\right) 45^{\circ} \mathrm{C}-5 \mathrm{dk} \\
\text { Durulama, } 25^{\circ} \mathrm{C}-5 \mathrm{dk}\end{array}$ \\
\hline
\end{tabular}

\subsection{Testler}

Parça yıkama ve ağartma işlemleri yapılmış kumaşlar standart atmosfer koşullarında $\left(20 \pm 2 \quad{ }^{\circ} \mathrm{C}\right.$ sıcaklık, $\% 65 \pm 4$ bağıl nem) kondüsyonlandıktan sonra kumaş gramajları, en büyük kopma kuvvet değerleri, yüzey sürtünme katsayıları, eğilme dayanımları ve renk farklılıkları ölçülmüştür. Kumaşların gramajları, TS 251 Madde 6'ya göre tespit edilmiştir [13]. Kumaşların atk1 ve çözgü yönündeki en büyük kopma kuvvet değerleri Zwick/Roell Z010 kopma mukavemeti test cihazında TS EN ISO 13934-1 standardına göre yapılmıştır [14]. Kinetik ve statik sürtünme katsayıları, Frictorq cihazında ölçülmüștür [15]. Eğilme dayanımı testi, TS 1409 standardına göre Shirley sertlik ölçer cihazında yapılmıştır [16]. İşlem görmemiş kumaş ile işlem gören kumaşların aralarındaki renk farklılı̆g $(\Delta \mathrm{E}$ değerleri) HunterLab marka spektrofotometre cihazında ölçülmüştür.

\section{BULGULAR ve TARTIŞMA}

\subsection{Gramaj Testi Sonuçları}

Sekil 2'de yıkama ve ağartma prosesleri uygulanmış ve herhangi bir işlem uygulanmamış kumaşlara ait gramaj değerleri verilmektedir.

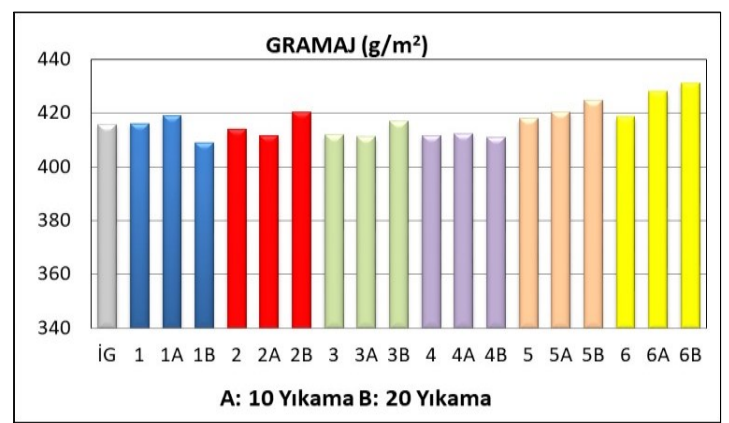

Şekil 2. Kumaşların gramaj değerleri

Şekil 2'de görüldüğü gibi işlem görmemiş kumaşa göre işlem gören ve yıkanan tüm numunelerin gramajlarının genel olarak arttığı görülmektedir. Hipoklorit ağartması (5 numaralı işlem) ve potasyum permanganat ağartması (6 numaralı işlem) uygulanan kumaşların gramajları işlemsiz ve diğer kumaşlara göre yaklaşık $10-15 \mathrm{~g} / \mathrm{m}^{2}$ kadar daha yüksektir. İşlemsiz kumaş gramaj değeri dikkate alındığında uygulamada bu farklılı̆ıın (yaklaşık \%3'lük artış) çok önemli olmadığı düşünülmektedir. Kumaş gramajlarındaki artışın sebebi yıkama sayısının artmasiyla birlikte artan mekaniksel etki ile suyun liflerin kesitlerini çok fazla şişirmesi ve dolayısıyla kumaşlarda meydana gelen boyutsal çekmedir.

Kumaşlara uygulanan farklı yıkama, ağartma ve yıkama işlemlerinin sayısının, kumaşların gramaj değerleri üzerine etkisini istatistiksel olarak belirlemek amaciyla varyans analizi testi gerçekleştirilmiştir. Test sonucuna göre uygulanan tüm işlemlerin etkisi $\alpha=0,05$ önem derecesiyle önemli iken $(\mathrm{p}=, 000)$, yıkama sayısının etkisinin önemsiz olduğu $(p=, 139)$ belirlenmiştir. Çizelge 6'da kumaş gramaj testine ait çoklu karşılaştırma testi sonuçları verilmektedir. Uygulanan yıkama ve ağartma prosesleri üç alt gruba ayrılmıştır. Aynı alt grupta yer alan gramaj değerleri, bu kumaşlara uygulanan yıkama ve ağartma işlemleri arasında istatistik olarak bir farklılık olmadığını göstermektedir. Dolayısıyla, en belirgin ve istatistiksel olarak önemli farklılık peroksit ağartması uygulanan kumaşların gramaj değerleri ile potasyum permanganat ağartmas uygulanan kumaşların gramaj değerleri arasındadir. 
Çizelge 6. Kumaş gramaj testine ait çoklu karşılaştırma analizi

\begin{tabular}{|c|c|c|c|c|}
\hline \multirow{2}{*}{ İşlem } & \multirow{2}{*}{$\mathbf{N}$} & \multicolumn{3}{|c|}{ Alt grup } \\
\hline & & 1 & 2 & 3 \\
\hline Peroksit ağartması & & 411,61 & & \\
\hline Taș ve enzim yıkama & 9 & 413,38 & 413,38 & \\
\hline Taș yıkama & 9 & 414,77 & 414,77 & \\
\hline Enzim yıkama & 9 & 415,32 & 415,32 & \\
\hline İşlemsiz & 9 & 415,83 & 415,83 & \\
\hline Hipoklorit ağartması & 3 & & 421,03 & 421,03 \\
\hline $\begin{array}{l}\text { Potasyum permanganat } \\
\text { ağartması }\end{array}$ & 9 & & & 425,93 \\
\hline Sig. & & ,648 & ,111 & ,118 \\
\hline \multirow{2}{*}{ Yıkama sayısı } & \multirow{2}{*}{$\mathbf{N}$} & \multicolumn{3}{|c|}{ Alt grup } \\
\hline & & \multicolumn{3}{|c|}{1} \\
\hline Y1kama yapılmamış & 21 & \multicolumn{3}{|c|}{415,13} \\
\hline 10 yıkama & 18 & \multicolumn{3}{|c|}{417,12} \\
\hline 20 yıkama & 18 & \multicolumn{3}{|c|}{418,89} \\
\hline Sig. & & \multicolumn{3}{|c|}{, 120} \\
\hline
\end{tabular}

\subsection{Kopma Mukavemeti Test Sonuçları}

Şekil 3 ve Şekil 4'de parça yıkama ve ağartma işlemleri yapılmış ve yapılmamış kumaşların sırasıyla atkı ve çözgü yönü en büyük kopma kuvveti değerlerine ait grafikler verilmektedir.

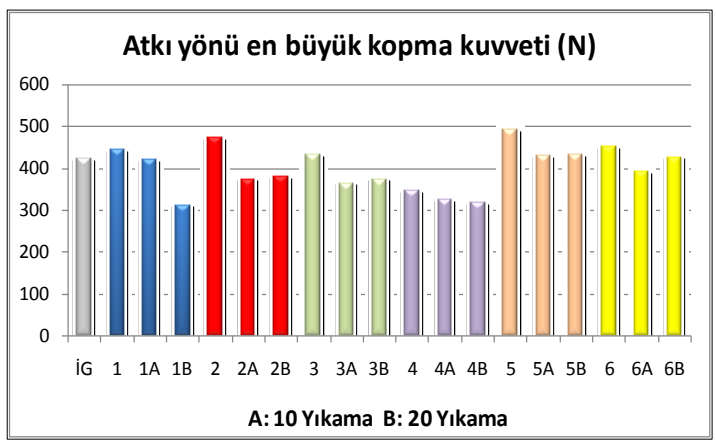

Şekil 3. Atk1 yönü kopma kuvveti sonuçları

Şekil 3'de görüldüğü gibi işlem görmemiş kumaşa göre işlem gören kumaşların bazılarında kopma kuvveti kumaştaki çekme sebebiyle artmıştır. Hipoklorit ağartması (5 numaralı işlem) sonrasında kumaşların atkı kopma kuvveti değerleri diğer kumaşlara göre çok daha yüksektir. Yıkama sayısı arttıkça mekanik etki nedeniyle lif kaybı oluşmakta ve dolayısıyla mukavemet düşmektedir. Mukavemet kaybı bakımından incelendiğinde; 20 yıkama sonrası taş yıkama (1 numaralı işlem) ve peroksit ağartması (4 numaralı işlem) sonrası en fazla mukavemet düşüşü saptanmıştır.
Kumaşların atkı yönü kopma kuvveti ölçüm sonuçları üzerine farklı yıkama, ağartma işlemlerinin ve yıkama işlemi sayısının etkisini belirlemek amaciyla gerçekleştirilen varyans analizi testinde incelenen her iki parametrelerinin etkisinin istatistiksel olarak önemli olduğu belirlenmiştir $(p=, 000)$. Çizelge 7'de kumaşların atk1 yönü kopma kuvveti testine ait çoklu karşılaştırma testi sonuçları verilmektedir. Çoklu karşılaştırma sonuçlarına göre de peroksit ağartması diğer proseslere göre önemli bir farklığa yol açarken, diğer işlemlerin aynı grupta olduğu belirlenmiştir. 10 ve 20 yıkama arasında önemli bir farklılık belirlenmemiştir, ancak yıkamanın yıkama yapılmamış kumaşa göre atkı yönü kopma kuvveti değerinde önemli bir azalmaya neden olduğu belirlenmiştir.

Çizelge 7. Kumaş atkı yönü kopma mukavemeti testine ait çoklu karşılaştırma analizi

\begin{tabular}{|c|c|c|c|}
\hline \multirow{2}{*}{ İşlem } & \multirow{2}{*}{$\mathbf{N}$} & \multicolumn{2}{|c|}{ Alt grup } \\
\hline & & 1 & 2 \\
\hline Peroksit ağartması & 9 & 327,07 & \\
\hline Taş yıkama & 9 & & 390,68 \\
\hline Enzim yıkama & 9 & & 406,45 \\
\hline Taş ve enzim yıkama & 9 & & 409,26 \\
\hline İşlemsiz & 3 & & 420,20 \\
\hline $\begin{array}{l}\text { Potasyum permanganat } \\
\text { ağartmas1 }\end{array}$ & 9 & & 420,84 \\
\hline Hipoklorit ağartması & 9 & & 449,57 \\
\hline Sig. & & 1,000 &, 194 \\
\hline \multirow{2}{*}{ Yıkama sayısı } & \multirow[b]{2}{*}{$\mathbf{N}$} & \multicolumn{2}{|c|}{ Alt grup } \\
\hline & & 1 & 2 \\
\hline 20 yıkama & 18 & 381,51 & \\
\hline 10 yıkama & 18 & 382,73 & \\
\hline Y1kama yapılmamış & 21 & & 435,20 \\
\hline Sig. & & ,936 & 1,000 \\
\hline
\end{tabular}

Şekil 4'de görüldüğü gibi yıkama ve ağartma işlemleri uygulanmış kumaşlarla kıyaslandığında işlem gören kumaşların bazılarında kopma mukavemeti artmıştır. Hipoklorit ağartması yapılmış (5 numaralı kumaş) kumaşların çözgü yönü en büyük kopma kuvvet değerleri diğer kumaşlara göre çok daha yüksektir. Genel olarak yıkama sayısı arttıkça mukavemet değerleri azalmıştır. Mukavemet kaybı açısından sonuçlar incelendiğinde, 20 yıkama sonrası peroksit ağartmasından (4 numaralı işlem) sonra en fazla mukavemet düşüşü saptanmıştır. 


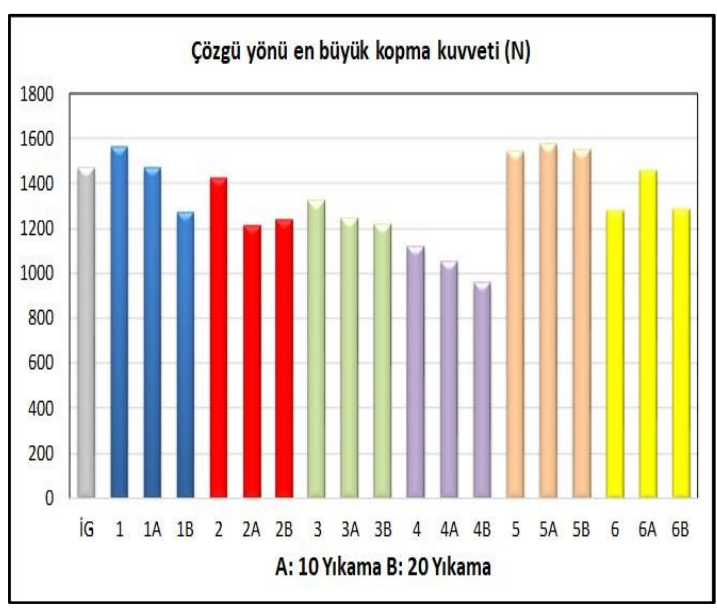

Şekil 4. Çözgü yönü kopma kuvveti sonuçları

Çözgü yönü en büyük kopma kuvvet değerlerinin değişken parametreler üzerine etkisi istatistiksel olarak incelendiğinde, denim kumaşlara uygulanan 6 farklı yıkama ve ağartma işleminin istatistiksel olarak etkili olduğu $(p=, 000)$, ancak yıkama sayısının etkisinin önemsiz olduğu $(\mathrm{p}=, 126)$ belirlenmiştir. Çizelge 8'de verilen çoklu karşılaştırma analizine göre denim kumaşlara uygulanan yıkama ve ağartma işlemleri 3 alt gruba ayrılmaktadır. En fazla kumaşa zarar veren işlem peroksit ağartmasıdır.

Çizelge 8. Kumaş çözgü yönü kopma mukavemeti testine ait çoklu karşılaştırma analizi

\begin{tabular}{|l|c|c|c|c|}
\hline \multirow{2}{*}{ İşlem } & \multirow{2}{*}{$\mathbf{N}$} & \multicolumn{3}{|c|}{ Alt grup } \\
\cline { 3 - 5 } & & 1 & 2 & 3 \\
\hline Peroksit ağartması & 9 & 1041,74 & & \\
\hline Taş ve enzim yıkama & 9 & & 1264,91 & \\
\hline Enzim yıkama & 9 & & 1289,04 & 1289,04 \\
\hline $\begin{array}{l}\text { Potasyum permanganat } \\
\text { ağartması }\end{array}$ & 9 & & 1338,19 & 1338,19 \\
\hline Taş yıkama & 9 & & 1432,13 & 1432,13 \\
\hline İşlemsiz & 3 & & 1469,15 & 1469,15 \\
\hline Hipoklorit ağartması & 9 & & & 1554,05 \\
\hline Sig. & & 1,000 &, 227 &, 060 \\
\hline Yıkama Sayısı & \multirow{3}{*}{ N } & \multicolumn{3}{|c|}{ Alt grup } \\
\cline { 3 - 5 } & 18 & \multicolumn{3}{|c|}{1249,48} \\
\hline 20 yıkama & 18 & \multicolumn{3}{|c|}{1325,82} \\
\hline 10 yıkama & 21 & \multicolumn{3}{|c|}{1380,70} \\
\hline Yıkama yapılmamış & & \multicolumn{3}{|c|}{066} \\
\hline Sig. & & \multicolumn{3}{|c|}{} \\
\hline
\end{tabular}

\section{Şekil 5. Kinetik sürtünme katsayısı değerleri}

Şekil 5'de işlem görmemiş kumaşa göre işlem gören kumaşların sürtünme katsayısı değerlerinin genel olarak arttığı görülmektedir. Bu sonucun, parça yıkama işlemleri sonrasındaki oluşan lif kayb1 sebebiyle kumaş yüzey pürüzlülüğünün artmasından kaynaklandığı düşünülmektedir. Yıkamanın etkisi açısından değerlendirildiğinde ise belirgin bir farklılık gözlenmemiştir.

Çizelge 9. Kinetik sürtünme katsayısı testine ait çoklu karşılaştırma analizi

\begin{tabular}{|c|c|c|c|c|c|}
\hline \multirow{2}{*}{ İşlem } & \multirow{2}{*}{$\mathbf{N}$} & \multicolumn{4}{|c|}{ Alt grup } \\
\hline & & 1 & 2 & 3 & 4 \\
\hline İşlemsiz & 3 &, 2546 & & & \\
\hline $\begin{array}{l}\text { Peroksit } \\
\text { ağartmas1 }\end{array}$ & 9 & & ,2798 & & \\
\hline $\begin{array}{l}\text { Potasyum } \\
\text { permanganat } \\
\text { ağartması }\end{array}$ & 9 & & ,2807 & & \\
\hline $\begin{array}{l}\text { Hipoklorit } \\
\text { ağartması }\end{array}$ & 9 & & ,2841 & ,2841 & \\
\hline $\begin{array}{l}\text { Taş ve enzim } \\
\text { yıkama }\end{array}$ & 9 & & & ,2940 & ,2940 \\
\hline Enzim yıkama & 9 & & & & ,2976 \\
\hline Taş yıkama & 9 & & & & ,2996 \\
\hline Sig. & & 1,000 & ,676 & ,055 &, 505 \\
\hline \multirow{2}{*}{$\begin{array}{l}\text { Yıkama } \\
\text { sayısı }\end{array}$} & \multirow{2}{*}{$\mathbf{N}$} & \multicolumn{4}{|c|}{ Alt grup } \\
\hline & & \multicolumn{2}{|c|}{1} & \multicolumn{2}{|c|}{2} \\
\hline $\begin{array}{l}\text { Yıkama } \\
\text { yapılmamış }\end{array}$ & 21 & \multicolumn{2}{|c|}{,2818 } & \\
\hline 20 yıkama & 18 & & & \multicolumn{2}{|c|}{,2888 } \\
\hline 10 yıkama & 18 & & & \multicolumn{2}{|c|}{,2927 } \\
\hline Sig. & 1,000 & \multicolumn{4}{|c|}{,211 } \\
\hline
\end{tabular}


Denim kumaşların Frictorq cihazında ölçülen kinetik sürtünme katsayısı değerlerine uygulanan yıkama, ağartma işlemlerinin ve yıkama sayısının etkisinin istatistiksel olarak belirlenmesi amaciyla gerçekleştirilen varyans analizi sonucunda işlemlerin etkisinin istatistiksel olarak önemli $(\mathrm{p}=, 000)$, yıkama sayısının $(\mathrm{p}=, 140)$ ise önemsiz olduğu belirlenmiştir. Çizelge 9'da verilen çoklu karşılaştırma analizine göre kumaşlar dört alt gruba ayrılmıştır. İşlemsiz kumaşlara göre diğer tüm yıkama ve ağartma işlemleri ayrı birer grupta yer almaktadır.

\subsection{Eğilme Dayanımı Sonuçları}

Şekil 6'da yıkama ve ağartma işlemleri yapılmış ve işlemsiz kumaşların eğilme dayanımlarına ait grafik verilmektedir.

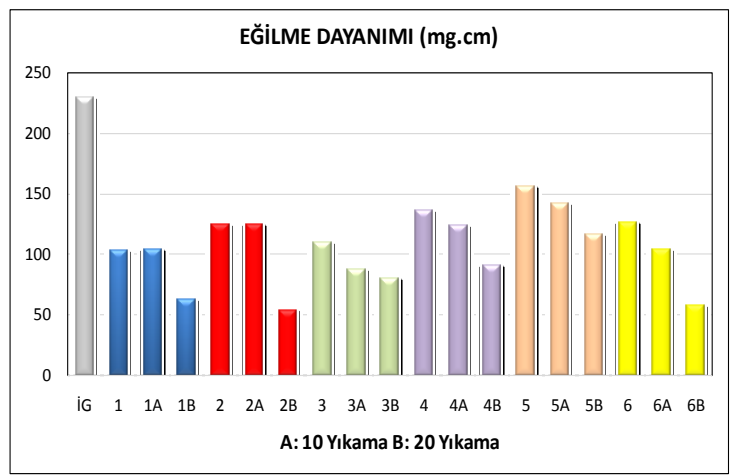

Şekil 6. Eğilme dayanımı değerleri

İşlem görmemiş kumaşa göre genel olarak işlem sonrasında eğilme dayanımlarında azalma olmuştur, yani kumaşların tuşesinin yumuşadığı söylenebilmektedir. Yumuşatma açısından en etkili işlemler, sadece taş (1 numaralı işlem) ve taş, enzim (3 numaralı işlem) birlikte olan yıkamalardır. Yıkama sayısı arttıkça yumuşaklık da artmıştır. Özellikle 20 yıkama yapılan numunelerin eğilme dayanımları oldukça düşük çıkmıştır. Taş yıkama (1B), enzim yıkama (2B) ve Potasyum permanganat (6B) ile aplikasyon yapılmış numuneler ile en düşük eğilme dayanımı değerleri elde edilmiştir (Şekil 6). Denim kumaşlara uygulanan yıkama, ağartma işlemlerinin ve yıkama sayısının kumaş tuşesi üzerindeki etkisini belirlemek amacıyla gerçekleştirilen eğilme dayanımı test sonuçlarına ait varyans analizinde her iki parametrenin etkisinin istatistiksel olarak önemli olduğu belirlenmiştir $(\mathrm{p}=, 000)$.

\subsection{Renk ölçümü sonuçları}

Şekil 7'de işlem görmemiş ve görmüş kumaşların renk farklılığına $(\Delta \mathrm{E})$ ait grafik verilmektedir.

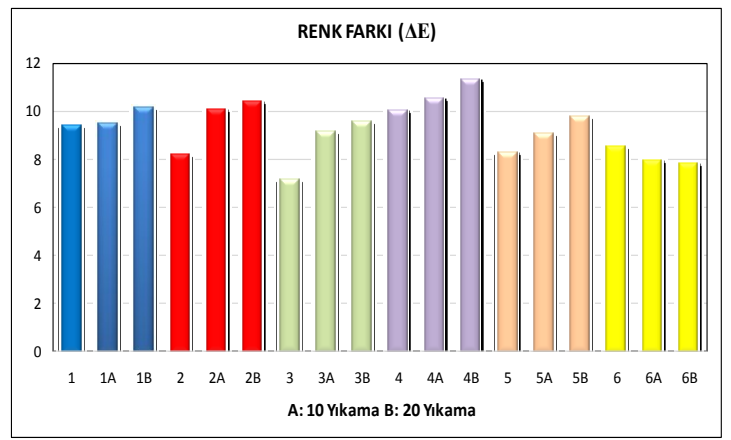

Şekil 7. $\Delta \mathrm{E}$ değerleri

Şekil 7'de görüldüğü gibi tüm yıkama ve ağartma işlemleri sonucunda kumaşların renk farklılık değerlerine bakıldığında, işlem görmemiş kumaşa göre önemli bir renk açılması söz konusudur. Y1kama öncesi numunelerin $\Delta \mathrm{E}$ değerlerine göre en etkili olan yani rengin en çok açıldığ $\breve{1}_{1}$ şlemlerin taş yıkama (1 numaralı işlem), enzim yıkama (2 numaralı işlem) ve peroksitle yapılan ağartma (4 numaralı işlem) olduğu belirlenmiştir. Bunun sebebi kimyasal işlemlerin lifin üzerindeki boyanın belirli bir kısmını liften koparmasıdır. Yıkama arttıkça renk açılması artmıştır. Yıkama sırasında uygulanan mekanik etkinin yanı sira hem sıcaklığın hem de kullanılan deterjanın etkisi nedeniyle kumaştan uzaklaşan boyarmadde miktarı fazladır ve bu sebeple de renk açılması daha fazla olmuştur. Yıkama etkisi, en çok 20 yıkamada ve peroksitle yapılan ağartma işleminde görülmüştür.

\section{SONUÇLAR}

Denim terbiyesinde yapılan farklı y1kama ve ağartma işlemleri ile kumaşların fiziksel özellikleri ve renkleri değişmektedir. Bu çalışmada, denim terbiyesinde uygulanan çeşitli yıkama ve ağartma işlemlerinin denim kumaşların gramajları, en 
büyük kopma kuvveti, sürtünme katsayısı, eğilme dayanımı ve renk değişimi özellikleri üzerine etkisi incelenmiştir. 6 farklı işlem ve 2 farklı yıkama sayısı ile toplamda 19 kumaş elde edilmiştir. $\mathrm{Bu}$ kumaşların yukarıda belirtilen ölçümleri sonucunda aşağıdaki sonuçlara ulaşılmıştır:

- Uygulanan yıkama ve ağartma işlemleri sonrasında işlem görmemiş kumaşa göre kumaş gramajlarında artış görülmüştür.

- Uygulanan işlemler arasında atkı yönünde kopma mukavemet düşüşü en fazla taş yıkama ve peroksit ağartma işlemlerinde saptanırken çözgü yönünde sadece peroksit ağartma işleminden sonra mukavemet düşüşü en fazladır. Tüm işlemlerde yıkama sayısı arttıkça mekanik etki nedeniyle lif kaybı oluşmakta ve dolayısıyla mukavemet düşmektedir.

- İşlem görmemiş kumaşa göre işlem gören kumaşların sürtünme katsayısı değerleri genel olarak incelendiğinde artmıştır. Yıkamalar sonucunda kumaşların sürtünme katsayısı değerlerinde belirgin bir farklılık gözlenmemiştir.

- İşlem görmemiş kumaşa göre genellikle işlemlerden sonrasında eğilme dayanımı değerlerinde oldukça fazla azalma olmuştur. Yani kumaşlar yumuşak tuşe kazanmıştır. Özellikle 20 yıkama sonrasında taş yıkama, enzim yıkama ve potasyum permanganat ile ağartma işlemleri sonrasında en düşük eğilme dayanımı değerleri elde edilmiştir.

- İşlem görmemiş kumaş ile işlem gören tüm kumaşların arasındaki renk farklılık değerleri önemlidir. Denim sektöründe uygulanan yıkama ve ağartma işlemlerinden beklenen en önemli etki, solma efektinin olabildiğince fazla olmasıdır. $\mathrm{Bu}$ açıdan düşünüldüğünde çalışmada yapılan tüm işlemler denimdeki solma efektinin elde edilmesinde etkili olmuştur. $\Delta \mathrm{E}$ değerlerine bakıldığında da bu solma etkisi açık bir şekilde görülmektedir. Rengin en çok açıldığı işlemler, taş yıkama, enzim yıkama ve peroksitle yapılan ağartma işlemleridir. Yıkama sayısı arttıkça renk açılması daha da artmıştır.

$\mathrm{Bu}$ çalışmada uygulanan yıkama ve ağartma işlemleri arasında en fazla renk açılmasının taş yıkama, enzim yıkama ve peroksitle ağartma ile gerçekleştiği tespit edilmiştir. Ancak peroksitle işlem sonrasında diğer işlemlere göre mukavemet kayıpları daha fazla olduğundan denim kumaşların yıkama işlemleri için en uygun prosesler taş ve enzim yıkama olarak önerilmektedir.

\section{KAYNAKLAR}

1. Aslan, M., Körlü A., 2009. Tekstil Teknolojileri Elektronik Dergisi, 3(1), 11-23.

2. Oğulata, R.T., Nergis A., 2017. Çukurova Üniversitesi Mühendislik Mimarlık Fakültesi Dergisi, 32(4), 87-98.

3. Karazincir, E., Baykal, P.D., 2014. Tekstil ve Mühendis, 21(94), 18-30.

4. Khalil, E., 2015. AASCIT Communications, 2(5), 159-163.

5. Khedher, F., Dhouib, S., Msahli, S., Sakli, F., 2009. Autex Research Journal, 9(3), 93-100.

6. Jucienè, M., Dobilaite, V., Kazlauskaitė, G., 2006. Materials Science (Medžiagotyra), 12, (4), 355-359.

7. Toksöz, M., Mezarciöz, S., Çukurova Üniversitesi 2013. Mühendislik Mimarlık Fakültesi Dergisi, 28(2), 141-147.

8. Hasan, M.Z., Mamun, M.A.A., Siddiquee, M.A.B., Asif, A.K.M.H., Kauser, M.A., 2017. American Journal of Engineering\& Natural Sciences, 1(2), 14-28.

9. Agrawal, B.J., 2017. Current Trends Biomedical Engineering \& Biosciences, 3(3)1-3.

10. Nergis, A., Oğulata, T., 2017. Tekstil ve Mühendis, 24(107), 160-171.

11. Munna K.H., Chinyerenwa A.C., Kamruzzaman, M., Asaduzzaman, Hossain, A., Rumi, T.M., 2016. Science Research, 4(6), 146-152.

12. Çakır, N., 2010. Kot Pantolon Üretiminde Bitim İşlemlerinin ve Farklı Denim Kumaşların Fit Üzerine Etkileri, Yüksek Lisans Tezi, 
Pamukkale Üniversitesi Fen Bilimleri Enstitüsü.

13. Türk Standartları Enstitüsü, 2008. TS 251 Standard1-Dokunmuş Kumaşlar-Birim Uzunluk ve Birim Alan Kütlesinin Tayini, https://intweb.tse.org.tr, 11.12.2017.

14. Türk Standartları Enstitüsü, 2002. TS EN ISO 13934-1 standard1-Tekstil-Kumaşların gerilme özellikleri-Bölüm 1: En Büyük Kuvvetin ve En Büyük Kuvvet Altında Boyca Uzamanın Şerit Yöntemiyle Tayini, https://intweb.tse.org.tr, alıntı tarihi:11.12.2017.

15. Lima, M., Hes, L., Vasconcelos, R., Martins, J., 2005. AUTEX Research Journal, 5(4), 194-201.

16. Türk Standartları Enstitüsü, 1973. TS 1409 Standard1-Dokunmuş Tekstil Mamullerinin Eğilme Dayanımı Tayini, https://intweb.tse.org.tr, alıntı tarihi:11.12.2017. 
